Louisiana State University

LSU Digital Commons

$1-1-2014$

\title{
Systematics of the obligate ant-following clade of antbirds (Aves: Passeriformes: Thamnophilidae)
}

Morton L. Isler

Smithsonian National Museum of Natural History

Gustavo A. Bravo

Louisiana State University

Robb T. Brumfield

Louisiana State University

Follow this and additional works at: https://digitalcommons.Isu.edu/biosci_pubs

\section{Recommended Citation}

Isler, M., Bravo, G., \& Brumfield, R. (2014). Systematics of the obligate ant-following clade of antbirds (Aves: Passeriformes: Thamnophilidae). Wilson Journal of Ornithology, 126 (4), 635-648. https://doi.org/ 10.1676/13-199.1

This Article is brought to you for free and open access by the Department of Biological Sciences at LSU Digital Commons. It has been accepted for inclusion in Faculty Publications by an authorized administrator of LSU Digital Commons. For more information, please contact ir@lsu.edu. 


\section{BioOne COMPLETE}

\section{Systematics of the obligate ant-following clade of antbirds (Aves: Passeriformes: Thamnophilidae)}

Authors: Isler, Morton L., Bravo, Gustavo A., and Brumfield, Robb T.

Source: The Wilson Journal of Ornithology, 126(4) : 635-648

Published By: The Wilson Ornithological Society

URL: https://doi.org/10.1676/13-199.1

BioOne Complete (complete.BioOne.org) is a full-text database of 200 subscribed and open-access titles in the biological, ecological, and environmental sciences published by nonprofit societies, associations, museums, institutions, and presses.

Your use of this PDF, the BioOne Complete website, and all posted and associated content indicates your acceptance of BioOne's Terms of Use, available at www.bioone.org/terms-of-use.

Usage of BioOne Complete content is strictly limited to personal, educational, and non - commercial use. Commercial inquiries or rights and permissions requests should be directed to the individual publisher as copyright holder.

BioOne sees sustainable scholarly publishing as an inherently collaborative enterprise connecting authors, nonprofit publishers, academic institutions, research libraries, and research funders in the common goal of maximizing access to critical research. 


\title{
SYSTEMATICS OF THE OBLIGATE ANT-FOLLOWING CLADE OF ANTBIRDS (AVES: PASSERIFORMES: THAMNOPHILIDAE)
}

\author{
MORTON L. ISLER, ${ }^{1,4}$ GUSTAVO A. BRAVO, ${ }^{2,3}$ AND ROBB T. BRUMFIELD ${ }^{2}$
}

\begin{abstract}
Results of a comprehensive molecular phylogeny of the family Thamnophilidae were consistent with earlier findings that almost all obligate army-ant-followers of the family form a monophyletic group that contains five wellsupported clades and encompasses six currently recognized genera: Phaenostictus, Pithys, Willisornis, Gymnopithys, Rhegmatorhina, and Phlegopsis. A comparative analysis of seven suites of morphological, behavioral, and ecological traits within the context of the phylogeny reinforced the validity of five of these genera, but results for the sixth, Gymnopithys, were internally inconsistent and required the description of a new genus, Oneillornis. Received 22 November 2013. Accepted 5 July 2014.
\end{abstract}

Key words: antbirds, Oneillornis, phylogeny, systematics, Thamnophilidae.

Early naturalists in the Neotropics (e.g., Bates 1863) observed birds following army ants and capturing arthropods fleeing their onslaught. More recently, some of these species have been characterized as obligate or professional antfollowers (Willis and Oniki 1978), because the birds were dependent on ant swarms to flush prey out of the leaf litter (reviewed in Willson 2004). Almost all obligate follower species are members of the family Thamnophilidae (Willson 2004), and within the family all but one obligate species are currently considered members of five genera (Gymnopithys, Rhegmatorhina, Phlegopsis, Pithys, or Phaenostictus) that, along with regular antfollowers of the genus Willisornis, belong in a monophyletic group that has maintained this phylogenetically conserved foraging specialization for millions of years (Brumfield et al. 2007). Recent phylogenies based on DNA sequence data (Brumfield et al. 2007, Aleixo et al. 2009) suggest that generic designations in the complex are in need of reexamination. Moving in that direction, Aleixo et al. (2009) found that a previously described ant-following genus, Skutchia (Willis 1968), was embedded in the genus Phlegopsis and recommended that the species in Skutchia be returned to Phlegopsis, where it had been placed originally by Hellmayr (1907).

\footnotetext{
${ }^{1}$ Department of Vertebrate Zoology-Birds, National Museum of Natural History, Smithsonian Institution, Washington, DC 20560, USA.

${ }^{2}$ Museum of Natural Science and Department of Biological Sciences, Louisiana State University, Baton Rouge, LA 70803, USA.

${ }^{3}$ Seção de Aves, Museu de Zoologia, Universidade de São Paulo, Caixa Postal 42.494, CEP 04218-970, São Paulo, SP, Brazil.

${ }^{4}$ Corresponding author; e-mail: antbird@cox.net
}

In a paper focused on the thamnophilid genus Myrmeciza (Isler et al. 2013), we considered the dilemma of setting generic limits. The choice is to establish genera solely on the basis of monophyly even though they might encompass phenotypically very different taxa-a "broad monophyly" option-or to narrow generic definitions to smaller, but more phenotypically homogeneous groups. After integrating various sources of phylogenetic, morphological, behavioral, and ecological variation in that paper, a "focused monophyly" approach was adopted as it provides recognition of phylogenetic relationships, genetic divergence, synapomorphic characters, and phenotypic distinctiveness that will best facilitate understanding and communication of relatedness of taxa among researchers, field workers and conservationists. Here, we use a similar approach to elucidate generic limits in the obligate armyant-following antbirds. After complementing the molecular data presented by Brumfield et al. (2007) with GenBank data and newly obtained sequences, we specifically focus on assessing generic boundaries among the ant-followers by overlaying this newly obtained phylogeny with a wide variety of morphological, behavioral, and ecological characteristics, most of which were unavailable when the vast majority of existing genera were described.

\section{METHODS}

We first constructed a molecular phylogeny of the core army-ant-following genera (sensu Brumfield et al. 2007) of the Thamnophilidae including Pithys, Gymnopithys, Rhegmatorhina, Phlegopsis, Phaenostictus, and the closely related genus Willisornis (Brumfield et al. 2007). We then 
identified morphological, behavioral, and ecological characters that were found consistently among species within well-supported clades and looked for distinct gaps in these characters between each clade and its close relatives. We based decisions to recognize genera on the extent of such gaps between monophyletic groups, keeping in mind phenotypic differences among universally accepted thamnophilid genera.

Taxon Sampling and Laboratory Procedures.Our analysis is based on DNA sequences from 57 vouchered specimens housed in accessible scientific collections (Peterson et al. 2007; Appendix $1)$. They represent all the currently recognized species (17) and genera (6) within the main obligate army-ant-following clade (sensu Brumfield et al. 2007), including samples of nominate populations of 16 species (only nominate Gymnopithys leucaspis was unavailable) and type species of all genera. For outgroups we used sequences from species in other thamnophilid genera: $E u$ chrepomis sharpei (LSUMZ 171313, tissue sample LSUMZ B-39086), Myrmornis torquata (FMNH 389880), Microrhopias quixensis (FMNH 321993), Thamnophilus doliatus (UWBM RTB390), Drymophila striaticeps (LSUMZ 98339, tissue sample LSUMZ B-572), and Hypocnemis striata (FMNH 391408).

Total DNA was extracted from $25 \mathrm{mg}$ of pectoral muscle using the Qiagen DNeasy kit, following the manufacturer's protocol. Based on the methods described in Brumfield et al. (2007), for 22 of the samples (Appendix) we amplified and sequenced three mitochondrial genes (nicotinamide dehydrogenase subunit 2 - ND2, $1,041 \mathrm{bp}$; nicotinamide dehydrogenase subunit 3 - ND3, 351 bp; cytochrome b - cytb, 1,045 bp) and one autosomal nuclear intron $(\beta$-fibrinogen intron 5 - $\beta \mathrm{F} 5,554 \mathrm{bp}$ ). We also amplified two coding nuclear genes (recombination activation gene 1 - RAG1, 2,857 bp; recombination activation gene 2 - RAG2, 1,152 bp) for one individual per genus following the methods described in Groth and Barrowclough (1999) and Barker et al. (2002). For the remaining samples we obtained sequences only for ND2. Some sequences were obtained from previous publications (Brumfield et al. 2007, Aleixo et al. 2009, Moyle et al. 2009, Gómez et al. 2010, Derryberry et al. 2011, Bravo et al. 2012, Naka et al. 2012). Analyses were conducted using two concatenated six-gene alignments containing $7,001 \mathrm{bp}$; one alignment only included the samples for which we had complete sampling of the mitochondrial genes and $\beta \mathrm{F} 5$, and the other alignment included all individuals. The motivation to have two separate alignments was to avoid potential biases resulting from missing data in the complete dataset. The reduced alignment would provide enough information to resolve the nodes informing intergeneric relationships in the obligate ant-followers and would minimize topology biases resulting from higher representation in the alignment of mtDNA than nucDNA.

We edited sequences using Sequencher 4.7 (Gene Codes Corporation, Ann Arbor, MI) and checked that protein-coding sequences did not include stop codons or anomalous residues. We aligned sequences using the program MAFFT V. 6 (Katoh et al. 2002), and obtained a concatenated dataset using Geneious Pro V5.5 (Drummond et al. 2011). Newly obtained sequences were deposited in GenBank (Accession numbers KM260369KM260414).

Phylogenetic Analyses.-We conducted ML analyses for six partition schemes under the GTR $+\Gamma$ model of nucleotide substitution using RAxML 7.2.7 (Stamatakis 2006) on the Cipres Science Gateway V 3.1 (Miller et al. 2010). We then calculated the Akaike Information Criterion (AIC) for each partition and established that the most informative scheme is the fully partitioned dataset (16 partitions; each codon position for each coding gene, and the nuclear intron for separate partitions). To evaluate nodal support of the fully partitioned dataset, we conducted a rapid bootstrap analysis in RAxML using 1,000 bootstrap replicates under the GTR $+\Gamma$ model of nucleotide substitution, following recommendations by the author in RAxML manual.

Using the same partition strategy followed in the likelihood analysis (16 partitions), we also performed a Bayesian analysis as implemented in Mr. Bayes 3.1.2 (Huelsenbeck and Ronquist 2001) on the Cipres Science Portal (Miller et al. 2010). To determine the best nucleotide substitution model for each partition, we used PAUP (Swofford 2003) to obtain likelihood values for the 24 substitution models featured in MrModeltest 2.3 (Nylander 2004). Table 1 summarizes the selected substitution model for each partition based on comparison of AIC scores. We conducted the analyses using four runs, four chains, and 2 $\times 10^{7}$ generations with a sample frequency of 1,000 , a burn-in of $20 \%$, and chain temperature of 1.75. The "compare" and "slide" functions of 
TABLE 1. Substitution model selected by MrModeltest for each of the 16 partitions included in the most informative partition strategy for both of the used alignments.

\begin{tabular}{|c|c|c|}
\hline Partition & Complete alignment & Reduced alignment \\
\hline RAG1-1st & GTR + I & \\
\hline RAG1-2nd & $\mathrm{GTR}+\mathrm{I}$ & \\
\hline RAG1-3rd & $\mathrm{HKY}+\Gamma$ & \\
\hline RAG2-1st & $\mathrm{HKY}+\mathrm{I}$ & \\
\hline RAG2-2nd & $\mathrm{HKY}+\mathrm{I}$ & \\
\hline RAG2-3rd & $\mathrm{HKY}+\Gamma$ & \\
\hline ND2-1st & $\mathrm{GTR}+\Gamma+\mathrm{I}$ & $\mathrm{GTR}+\Gamma$ \\
\hline ND2-2nd & GTR + I & \\
\hline ND2-3rd & $\mathrm{GTR}+\Gamma+\mathrm{I}$ & \\
\hline ND3-1st & $\mathrm{HKY}+\Gamma$ & $\mathrm{K} 80+\Gamma$ \\
\hline ND3-2nd & $\mathrm{GTR}+\Gamma+\mathrm{I}$ & \\
\hline ND3-3rd & GTR $+\Gamma$ & \\
\hline cytb-1st & $\mathrm{SYM}+\Gamma+\mathrm{I}$ & \\
\hline cytb-2nd & $\mathrm{GTR}+\mathrm{I}$ & \\
\hline cytb-3rd & $\mathrm{GTR}+\Gamma$ & \\
\hline$\beta \mathrm{F} 5$ & $\mathrm{HKY}+\Gamma$ & \\
\hline
\end{tabular}

AWTY online (Wilgenbusch et al. 2004) were used to assess the performance of Bayesian phylogenetic inference.

Taxonomic Assessment.-Principal well-supported clades recovered in the phylogenetic analyses provided the foundation upon which we assessed phenotypic differences to make generic recommendations. To make trait comparisons and establish diagnosability of the identified groups, we used a recent compilation of thamnophilid information (Zimmer and Isler 2003) to extract plumage, behavioral, and ecological data whose original sources may be obtained from the publication. We supplemented these data by more recent sources cited herein and by measuring 10 morphological variables (wing length, primary 10 length, tail length, rectrix 1 width, secondary 1 length, bill length from nostril to tip, bill width at nostrils, bill depth at nostrils, tarsus length, hallux length) from 82 individuals (Appendix 2). All measurements were taken to the nearest $0.01 \mathrm{~mm}$ with a Mitutoyo Digimatic Point Caliper by G.A.B. Details of how they were taken can be found elsewhere (Baldwin et al. 1931, Derryberry et al. 2011). To assess diagnosability among clades, we compared mean values of ecomorphological variation among clades, and conducted discriminant function analyses (DFA) using logtransformed measurements for all individuals in currently recognized genera as well as potentially new genera.

\section{RESULTS}

Molecular Analysis.-Maximum-likelihood and Bayesian analyses of both datasets (i.e., all individuals vs. individuals with complete gene sampling only) produced similar topologies indicating with high support that the core clade of obligate army-ant-followers (henceforth, the complex) contains five well-supported clades within it (Figs. 1, 2). Among currently recognized genera, only Gymnopithys was recovered as non-monophyletic. The only discrepancies between maximumlikelihood and Bayesian inference trees are: (1) the position of Willisornis; the former places it as sister to a clade containing Phlegopsis, Gymnopithys, and Rhegmatorhina, whereas the latter recovers it as sister to a clade containing only Gymnopithys and Rhegmatorhina. and (2) the relationships among clades identified on the figures as Gymnopithys 1, Gymnopithys 2, and Rhegmatorhina, the basal node of which is unresolved in both cladograms.

From here on, principal clades are identified by the genera they include and subclades by the oldest name among their constituent species. The clades (numbered following Figs. 1, 2) include: (1) the Phaenostictus clade; (2) the Pithys clade; (3) the Willisornis clade; (4) the Phlegopsis clade that includes three subclades: (4a) the erythroptera clade; (4b) the borbae clade; and (4c) the nigromaculata clade; and (5) the Gymnopithys/ Rhegmatorhina clade that also include three subclades: (5a) the rufigula clade containing Gymnopithys leucaspis and G. rufigula; (5b) the lunulatus clade containing $G$. lunulatus and $G$. salvini; and (5c) the gymnops clade, which contains five species in the genus Rhegmatorhina.

Morphological Variation among Obligate Army-AntFollowing Birds.-All clades differed diagnostically in plumage (Table 2). On the other hand, the ant-followers share many morphometric similarities (Tables 3, 4). Component measurements (e.g., wing length) are in most cases proportional to size. Clades differ principally in size and bulk as reflected in the ratio between weight and body length, for which every clade differs from its closest relative except for the rufigula and gymnops clades. Remaining differences in morphometric proportions (Table 4) primarily involve bill measurements. Because bill length is similar across all clades regardless of size, larger species exhibit significantly smaller ratios of bill size to total length. However, bill proportions were consistent across all clades except for the 


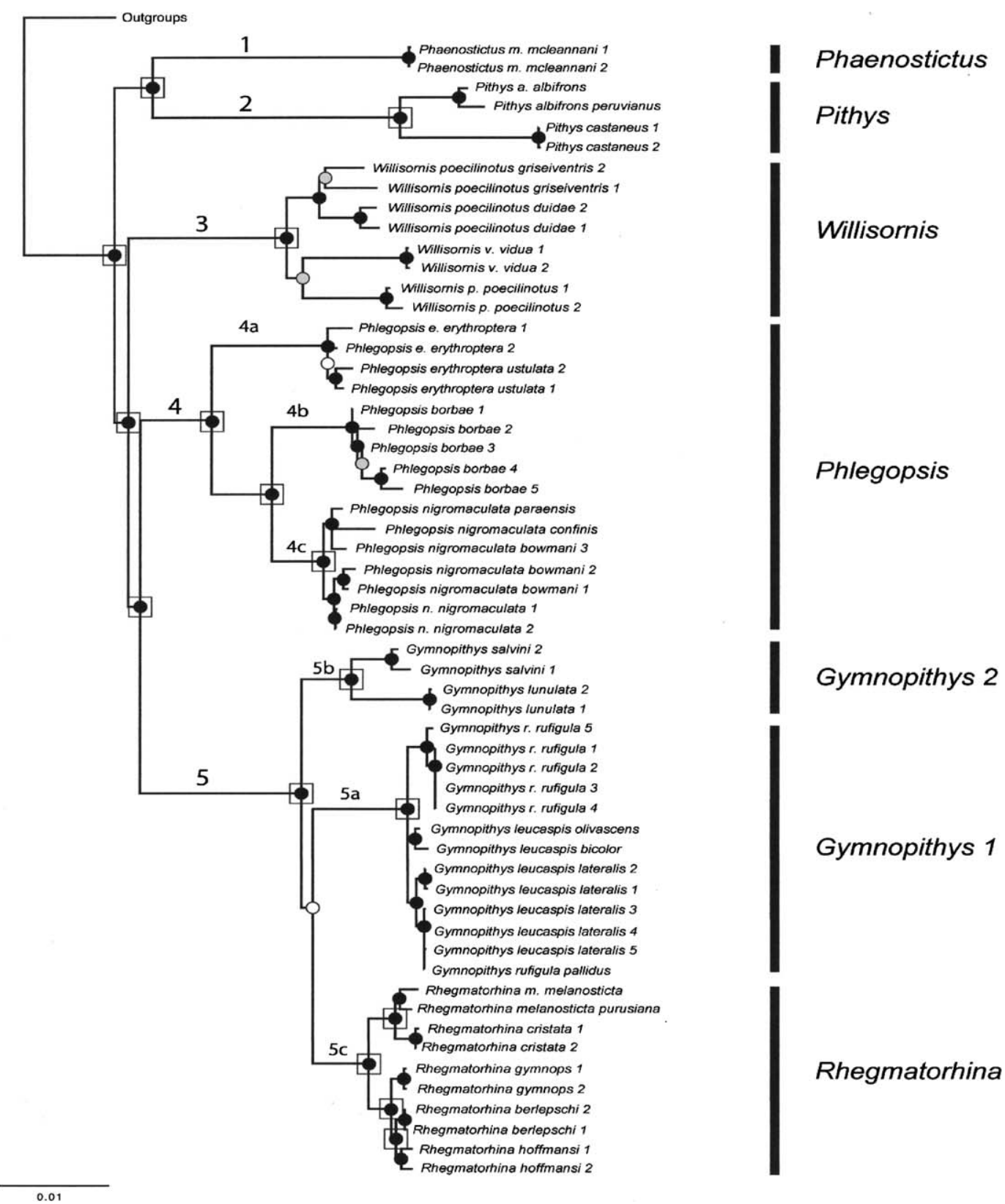

FIG. 1. Maximum-likelihood tree of the core obligate-army-ant-following thamnophilids, showing that they represent a monophyletic group. All genera, with the exception of Gymnopithys, represent monophyletic groups. The color of the circles at nodes indicates bootstrap support values, $>70 \%$ (black), 50-70\% (gray), $<50 \%$ (white). Hollow squares around some nodes represent highly supported nodes $(>70 \%)$ in the analysis performed using samples with no missing mtDNA and $\beta \mathrm{F} 5$ data.

relatively deeper bills of the nigromaculata and erythroptera clades. The proportionately longer tail of the Phaenostictus clade was the only other significant difference.
A discriminant function analysis of $10 \mathrm{log}$ corrected ecomorphological features showed that all five principal clades identified solely on the basis of monophyly are diagnosable (Wilks' 


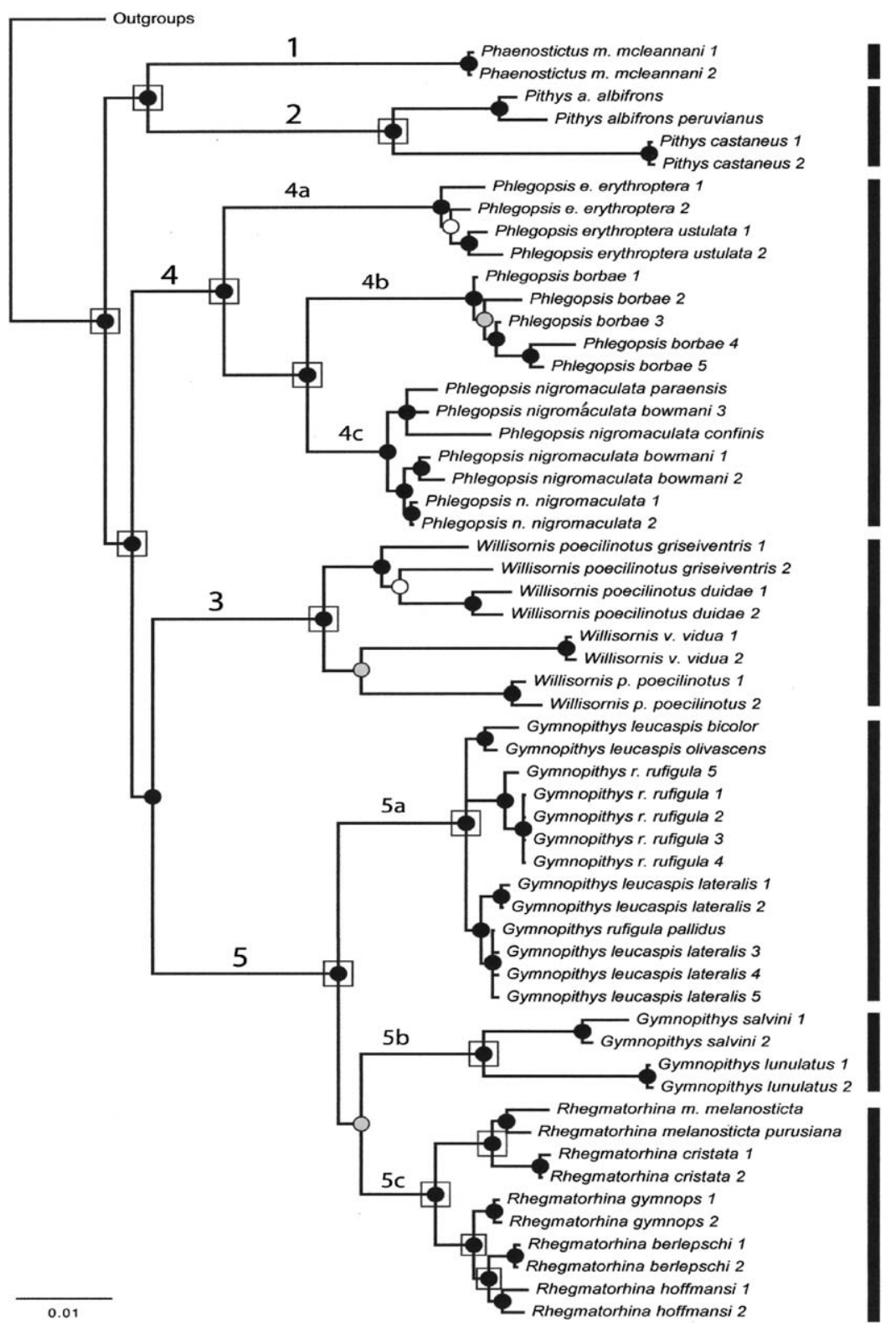

Phaenostictus

Pithys

Phlegopsis

\section{Willisornis}

Gymnopithys 1

Gymnopithys 2

Rhegmatorhina

FIG. 2. Fifty percent majority-rule Bayesian consensus tree of the core obligate-army-ant-following thamnophilids, showing that they represent a monophyletic group. All genera, with the exception of Gymnopithys, represent monophyletic groups. The color of the circles at nodes indicates posterior probability values, $>0.95$ (black), $0.95-0.75$ (gray), $<0.75$ (white). Hollow squares around some nodes represent highly supported nodes $(>0.95)$ in the analysis performed using samples with no missing mtDNA and $\beta$ F5 data.

lambda $\left.=0.005, F_{4,77}=20.4, P<0.0001\right)$. All individuals were correctly assigned in their clade (Fig. 3). The first discriminant function separated groups primarily on differences in length of the first secondary remige and tarsus (LD1 $=67.1 \%$ ), whereas the second function discriminated groups based on differences in wing, tarsus, and tail length $(\mathrm{LD} 2=17.4 \%)$.

Loudsong Variation among Obligate Army-AntFollowing Birds.-As can be seen in Figure 4, loudsongs of species in the Willisornis (Fig. 4A), Phaenostictus (Fig. 4B), and Pithys (Fig. 4C; P. 
TABLE 2. Plumage description of clades and subclades identified within the obligate army-ant-following birds.

\begin{tabular}{|c|c|c|}
\hline Clade/subclade & Name & Plumage description \\
\hline 1 & Phaenostictus & $\begin{array}{l}\text { Monomorphic. Black head surmounted by a large blue periorbital patch, olive-gray crown, } \\
\text { and rufous nape; body feathers above and below with large black subterminal spots edged } \\
\text { cinnamon-buff; and a blackish-brown tail }\end{array}$ \\
\hline 2 & Pithys & $\begin{array}{l}\text { Monomorphic. Extensive rufous-chestnut body coloration and a contrasting black head with } \\
\text { white throats and feather tufts or periocular patch; tarsi and feet orange }\end{array}$ \\
\hline 3 & Willisornis & $\begin{array}{l}\text { Dimorphic. Males are gray and black and females predominantly brown. Males show } \\
\text { extensive white or whitish edges to the wing coverts and lower back. Females either have a } \\
\text { wing covert pattern similar to the male or gray underparts. }\end{array}$ \\
\hline $4 a$ & erythroptera & $\begin{array}{l}\text { Dimorphic. Males predominantly black with whitish edges in upper back, and rufous wing } \\
\text { coverts and remiges. Females predominantly brown with whitish wing coverts. Both sexes } \\
\text { have a red periorbital patch. }\end{array}$ \\
\hline $4 \mathrm{~b}$ & borbae & $\begin{array}{l}\text { Monomorphic. Predominantly brown with elongated white feathers on forehead and lores, and } \\
\text { with barred black and white band across upper belly. }\end{array}$ \\
\hline $4 \mathrm{c}$ & nigromaculata & $\begin{array}{l}\text { Monomorphic. Head and neck down to belly black. Upperparts and wing coverts } \\
\text { predominantly light olive, covered with black spots of varying size and edgings. Remiges } \\
\text { primarily rufous. }\end{array}$ \\
\hline $5 a$ & rufigula & $\begin{array}{l}\text { Monomorphic except for interscapular patches in some taxa. Blue periorbital patch with upperparts } \\
\text { predominantly brown and lighter to with lower parts. No scaling or barring is found. }\end{array}$ \\
\hline $5 b$ & lunulatus & $\begin{array}{l}\text { Dimorphic. Males predominantly gray with supercilium, chin, and throat white. Females } \\
\text { predominantly brown with barred tail. }\end{array}$ \\
\hline $5 c$ & gymnops & $\begin{array}{l}\text { Dimorphic. Both sexes share a fairly prominent crest, light periorbital patches, and plain } \\
\text { brownish tail. Males with upper parts predominantly brown. Females with lower parts } \\
\text { predominantly brown. Dark masks are common in both sexes. A scaling pattern in back is } \\
\text { common in females. }\end{array}$ \\
\hline
\end{tabular}

albifrons, the note of $P$. castaneus ascends) clades are structurally distinct from the remaining clades whose series of notes primarily descend in frequency. Loudsongs of the three sub-clades in the Phlegopsis clade are simple descending series (Fig. 4D-F). Notes in loudsongs of species in the Gymnopithys/Rhegmatorhina clade typically rise in frequency or are flat before falling (Fig. 4G-I), although notes of Gymnopithys salvini (Fig. 4J) simply descend like loudsongs in the Phlegopsis clade. Note that the two species in the lunulatus clade differ structurally. Note peaks of lunulatus rise and fall in frequency as notes lengthen, whereas the longer notes of salvini descend while remaining similar in duration. These are the only structurally inconsistent loudsongs within any of the clades.

Nest Variation among Obligate Army-AntFollowing Birds.-Forty-five nests have been described for nine of the 17 species included. All nests were supported from below (not hung from branches) and were cup-shaped (not domed) although a few were so shallow as to barely resemble a cup. However, substrate placement of

TABLE 3. Morphometrics. Body length $=$ Total length - Tail length. All measurements in mm except weight in g.

\begin{tabular}{|c|c|c|c|c|c|c|c|c|c|c|c|c|c|}
\hline Clade/subclade & $\begin{array}{l}\text { Total } \\
\text { length }\end{array}$ & $\begin{array}{l}\text { Body } \\
\text { length }\end{array}$ & Weight & $\begin{array}{l}\text { Wing } \\
\text { length }\end{array}$ & $\begin{array}{c}\text { Primary } \\
\text { length }\end{array}$ & $\begin{array}{c}\text { Secondary } \\
\text { length }\end{array}$ & $\begin{array}{c}\text { Tail } \\
\text { length }\end{array}$ & $\begin{array}{l}\text { Tail } \\
\text { width }\end{array}$ & $\begin{array}{c}\text { Bill } \\
\text { length }\end{array}$ & $\begin{array}{c}\text { Bill } \\
\text { width }\end{array}$ & $\begin{array}{r}\text { Bill } \\
\text { depth }\end{array}$ & $\begin{array}{l}\text { Tarsus } \\
\text { length }\end{array}$ & $\begin{array}{l}\text { Hallux } \\
\text { length }\end{array}$ \\
\hline 1 Phaenostictus & 192 & 108 & 50 & 88 & 62 & 79 & 84 & 14.8 & 13.8 & 5.3 & 6.7 & 32.6 & 19.9 \\
\hline 2 Pithys & 130 & 84 & 26 & 74 & 55 & 64 & 46 & 10.1 & 11.6 & 4.7 & 4.8 & 23.4 & 15.4 \\
\hline 3 Willisornis & 125 & 84 & 17 & 66 & 46 & 57 & 41 & 8.9 & 11.2 & 4.6 & 4.4 & 23.2 & 16.5 \\
\hline 4a erythroptera & 182 & 117 & 58 & 92 & 66 & 85 & 65 & 15.6 & 12.4 & 5.0 & 5.9 & 33.9 & 20.7 \\
\hline 4b borbae & 170 & 116 & 43 & 85 & 63 & 79 & 54 & 16.1 & 12.1 & 4.8 & 6.5 & 31.4 & 19.9 \\
\hline 4c nigromaculata & 170 & 115 & 47 & 87 & 62 & 80 & 55 & 11.8 & 11.4 & 4.7 & 5.8 & 31.4 & 20.5 \\
\hline 5a rufigula & 130 & 86 & 27 & 74 & 53 & 67 & 46 & 10.4 & 11.6 & 5.0 & 4.9 & 27.0 & 17.1 \\
\hline 5b lunulatus & 132 & 88 & 24 & 71 & 50 & 65 & 44 & 9.9 & 12.2 & 4.9 & 4.7 & 25.5 & 16.9 \\
\hline 5c gymnops & 144 & 93 & 29 & 77 & 55 & 70 & 51 & 10.6 & 12.3 & 4.8 & 5.0 & 27.4 & 17.3 \\
\hline
\end{tabular}




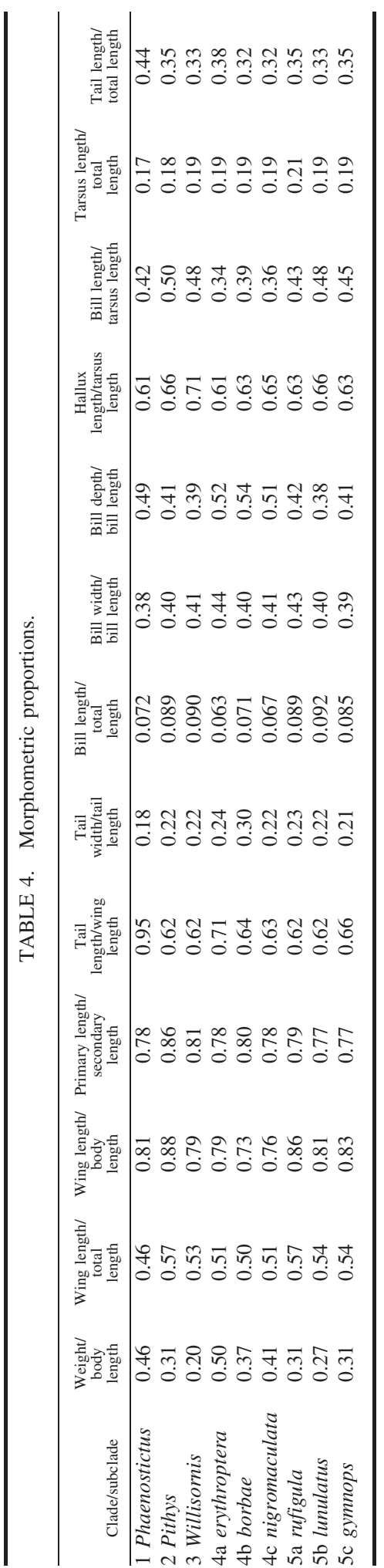

nests varied. Most commonly, 20 nests for seven species were placed in hollow stumps within a few meters of the ground. Alternative nest sites for these seven species were hollows formed at the base of palm fronds (six nests for three of the species), cavities in live trees (two species), and in litter at the base of a tree (one species). Substrate placement differed for nests of the two remaining species. Eleven recently described Phaenostictus mcleannani nests (Buehler et al. 2004, Class and Chaves-Campos 2009) were placed between tree buttresses on the ground (although one was slightly elevated). The smaller sample (four nests) of Pithys albifrons were all placed atop live vegetation (two atop small palms, one in sedge, and one in a clump of tuberous plants). Although nests of species in all clades were bottomsupported cups, differences in substrate placement appear relevant to generic considerations.

Other Considerations.-Other than morphology, loudsongs, and nest architecture, no intrinsic or supporting behavioral or ecological traits provide distinctions among clades relevant to distinguishing obligate ant-follower genera. Tail movement, an intrinsic trait distinguishing other thamnophilid clades (Isler et al. 2013), was consistent in all clades. Foraging behavior, diet (Chesser 1995), and habitat, which often provide supporting evidence of generic distinctions, were also found to be almost entirely consistent, the exception being that species in the Willisornis clade are considered regular rather than obligate ant-followers.

Hybridization between species may provide another insight in generic considerations. Especially noteworthy is a specimen originally described as a species but later shown to be a hybrid between species in the erythroptera and nigromaculata sub-clades (Graves 1992). Curiously, although hybridization among thamnophilid species is rare (Graves 1992), hybrids have also been found between species within the gymnops clade (Rhegmatorhina berlepschi and R. hoffmannsi hybridize extensively in the upper MadeiraTapajós interfluvium, and genetic introgression between them is currently under study; B. M. Whitney, pers. comm.) and the rufigula clade (individual identified as Gymnopithys rufigula pallidus in Naka et al. 2012 and in Figs. 1,2).

\section{DISCUSSION}

The integration of modern genetic studies with traditional phenotypic data provides a powerful 


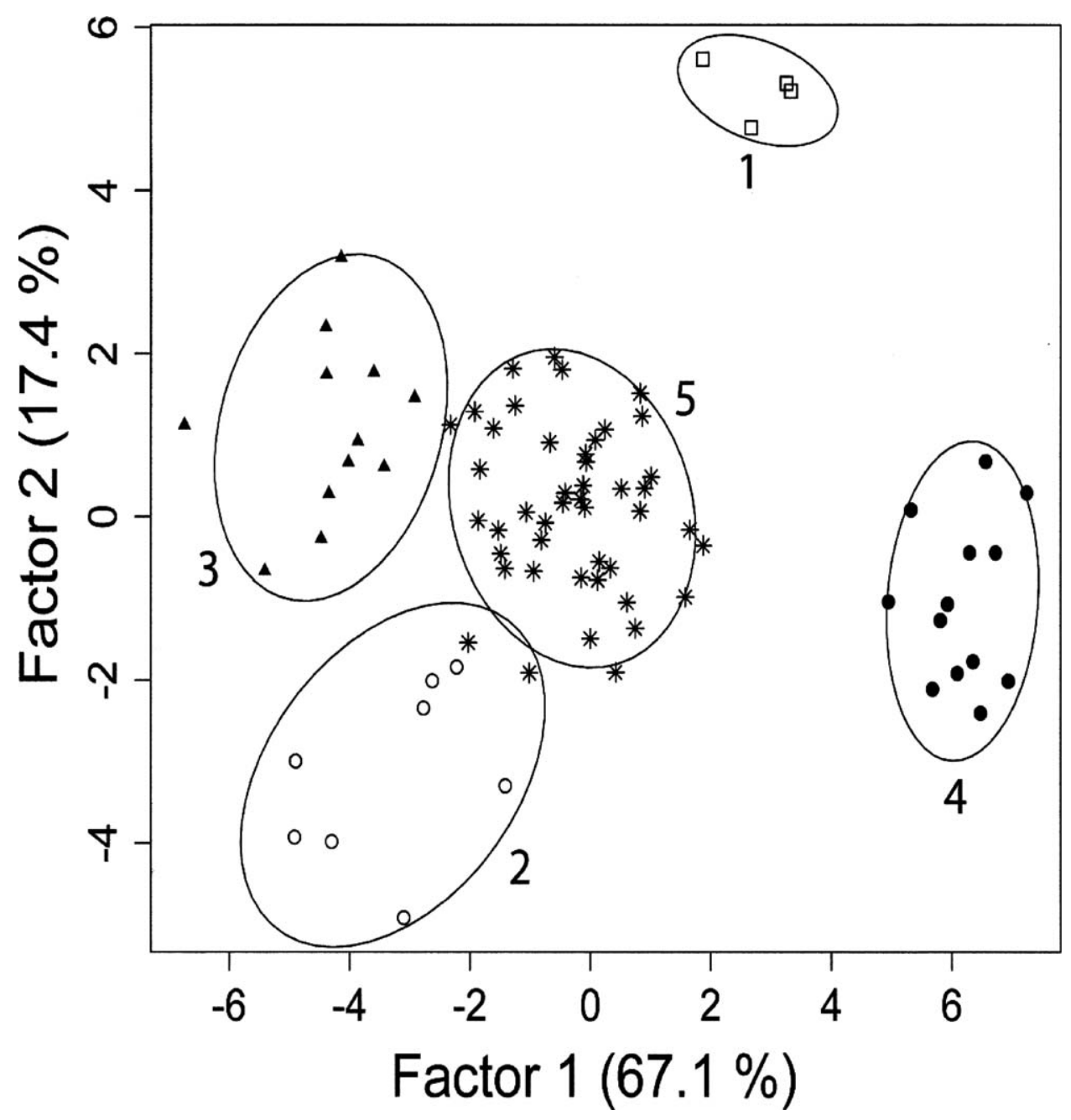

FIG. 3. Discriminant factors of ecomorphological variation of the core obligate-army-ant-following thamnophilids following a plausible genus-level classification scheme based solely on the monophyly of the main clades in the group. Positive values of Factor 1 represent longer secondary 1 feathers and longer tarsi. Positive values of Factor 2 represent longer tails and longer tarsi. Ellipses represent $95 \%$ confidence intervals. Numbers next to ellipses indicate clades they represent. (1) Phaenostictus; (2) Pithys; (3) Willisornis; (4) Phlegopsis; and (5) Gymnopithys/Rhegmatorhina.

new tool to overcome the difficulties of generic designations, especially problems of homoplasy. Instances of homoplasy are prevalent in obligate ant-followers, in which a variety of morphological characters (e.g., black-spotted back feathers) are found in the plumages of otherwise morphologically distinct taxa (Aleixo et al. 2009). Evolutionary relationships uncovered in molecular-based phylogenies provide the structure, unavailable to earlier systematists, for a taxonomic classification that reflects the evolutionary history of the group.
The molecular phylogeny identified five principal clades of ant-followers. Three of these clades are restricted currently to species placed in a single genus: (1) Phaenostictus; (2) Pithys; and (3) Willisornis. Our results were consistent with the maintenance of these three genera, finding that they are distinguished by plumage, by morphometric measurements related to differences in size and bulk, and by the structure of their loudsongs. Behavioral support includes apparently distinct nest placement in Phaenostictus and regular rather than obligate ant-following 

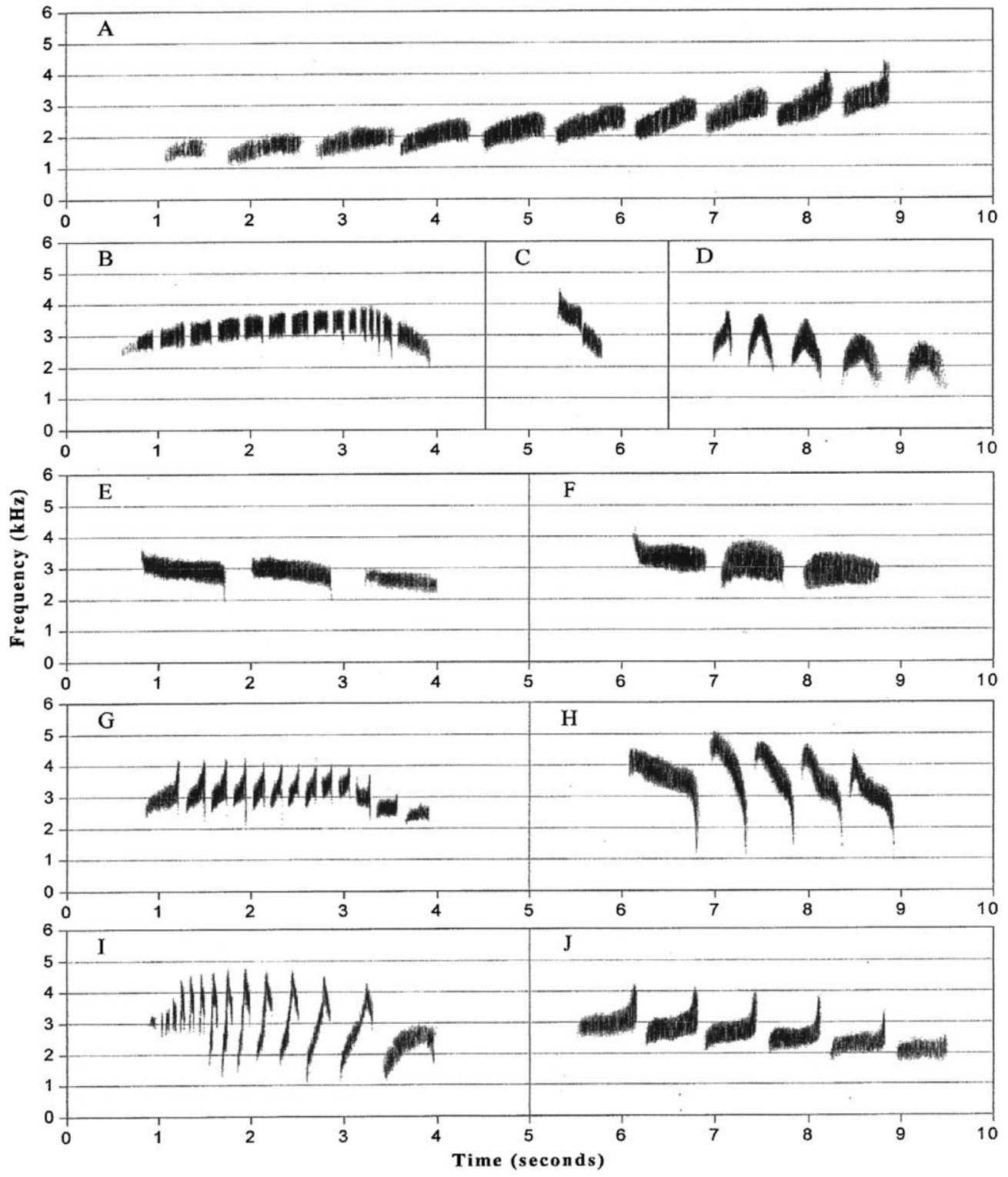

FIG. 4. Loudsongs of representative species of ant-following thamnophilids showing note structure characteristic of clades. Loudsongs of both Gymnopithys lunulatus and G. salvini are shown because structurally they are inconsistent. A. Willisornis poecilinotus (Clade 3) São Gabriel da Cachoeira, Amazonas, Brazil (Whitney ISL-BMW.79:08). B. Phaenostictus mcleannani (Clade 1) Kuna Yala Indian Reserve, San Blas, Panama (Whitney ISL-BMW.17:33). C. Pithys albifrons (Clade 2) Quebrada Sucusari, Loreto, Peru (Parker/Budney MLNS 34305). D. Phlegopsis erythroptera (Clade 4a) Libertad, Loreto, Peru (Parker MLNS 29314). E. Phlegopsis borbae (Clade 4b) Borba, Amazonas, Brazil (Whitney ISLBMW.190:29). F. Phlegopsis nigromaculata (Clade 4c) Serra dos Carajás, Pará, Brazil (Whitney ISL-BMW.63:16). G. Gymnopithys rufigula (Clade 5a) El Palmar, Bolívar, Venezuela (Schwartz MLNS 62174). H. Rhegmatorhina gymnops (Clade 5c) Rio São Benedito, Pará, Brazil (Whitney ISL-BMW.176:06). I. Gymnopithys lunulatus (Clade 5b example 1) Liborio, Loreto, Peru (Whitney ISL-BMW.93:116). J. Gymnopithys salvini (Clade 5b example 2) Explorer's Inn, Madre de Dios, Peru (Parker MLNS 23814). 
in Willisornis. Species limits within Willisornis should be assessed further, because the relationship between its two currently recognized species, $W$. poecilinotus and $W$. vidua, remains unresolved. This was not unexpected based on a previous morphological and vocal analysis (Isler and Whitney 2011).

The phylogeny identified subclades within each of the remaining two principal clades. The Phlegopsis clade (4) includes the erythroptera, borbae, and nigromaculata subclades. Plumage differences had led to the placement of borbae in a monotypic genus (Skutchia) and the others in Phlegopsis, but an earlier phylogenetic study (Aleixo et al. 2009) showed that this treatment rendered Phlegopsis paraphyletic and concluded that plumage differences among the three clades and sexual dimorphism in erythroptera were insufficient to relegate the clades to three genera. The phylogenetic results and phenotypic comparisons of the present study are consistent with the earlier recommendations (Cory and Hellmayr 1924, Aleixo et al. 2009) to maintain all three subclades in Phlegopsis.

The final principal clade (5) includes the rufigula, lunulatus, and gymnops subclades. Although the basal node of the lunulatus, gymnops, rufigula clade is not resolved, and species limits within rufigula seem unresolved, our results as well as those of Brumfield et al. 2007 indicate that the rufigula, lunulatus, and gymnops subclades represent distinct lineages. The rufigula and lunulatus subclades are currently placed in Gymnopithys and the gymnops subclade in Rhegmatorhina. Given the substantial distinctions between them in plumage, consolidating Gymnopithys and Rhegmatorhina into a single genus (Gymnopithys has priority) is inconsistent with the "focused monophyly" approach. However, if the genus Rhegmatorhina is recognized, the rufigula and lunulatus subclades cannot be maintained in the same genus under the principle of monophyly. We conclude that Rhegmatorhina should be maintained, that Gymnopithys be restricted to the rufigula subclade, and that a new genus must be erected for the lunulatus subclade.

Taxonomic recommendations.-We recommend that species in the obligate ant-follower clade be maintained in seven genera, six of which are recognized, and one of which requires a new name. The following diagnoses are placed in context of the phylogeny. Consequently, pheno- typic comparisons are primarily of sister clades. English names follow Remsen et al. (2013).

\section{Phaenostictus Ridgway, 1909}

Type species.-Phlogopsis mcleannani Lawrence, 1837.

Included species.-Phaenostictus mcleannani (Lawrence 1837) OCELLATED ANTBIRD.

Diagnosis.-Both sexes distinguished by a combination of plumage characters including black sides of head and throat, a large blue periorbital patch, olive-gray crown, and rufous nape; body feathers above and below with large black subterminal spots edged cinnamon-buff; and a blackish-brown tail. Morphometrically distinguished from all genera in the complex by an unusually long tail and from its close relatives by its large size and weight. Loudsong a long rapid series that rises and falls in pitch, structurally unique in complex.

\section{Pithys Vieillot, 1818}

Type species.-Pipra albifrons Linnaeus, 1766. Included species.-Pithys albifrons (Linnaeus 1766) WHITE-PLUMED ANTBIRD.

Pithys castaneus (Berlioz 1938) WHITE-MASKED ANTBIRD.

Diagnosis.-Distinguished in both sexes by extensive rufous-chestnut body coloration and contrasting black head with white throat and feather tufts or periocular patch; tarsi and feet orange. Morphometrically distinguished from closest relative (Phaenostictus) by its smaller size (length and weight) and shorter tail (relative to total length and wing length). Loudsong a single whistle, structurally unique in complex.

\section{Willisornis Agne and Pacheco, 2007}

Type species.-Hypocnemis poecilinota Cabanis, 1847.

Included species.-Willisornis poecilinotus (Cabanis 1847) COMMON SCALE-BACKED ANTBIRD.

Willisornis vidua (Hellmayr 1905) XINGU SCALE-BACKED ANTBIRD.

Diagnosis.-Distinguished from all in complex except Oneillornis by the combination of gray and black male plumage and predominantly brown female plumage. Males differ from Oneillornis by extensive white or whitish edges to the wing coverts and lower back reflected in their vernacular name. Females differ from Oneillornis either by a wing covert pattern similar to the male or by gray underparts. Morphometrically slighter (weighs less) than all others in complex. Loud- 
songs a slow series rising in pitch, structurally unique in the complex.

\section{Phlegopsis Reichenbach, 1850}

Type species.-Myothera nigro-maculata d'Orbigny and Lafresnaye, 1837.

Included species.-Phlegopsis nigromaculata (d'Orbigny and Lafresnaye, 1837) BLACK-SPOTTED BARE-EYE.

Phlegopsis borbae Hellmayr, 1907 PALE-FACED BARE-EYE.

Phlegopsis erythroptera (Gould 1855) REDDISH-WINGED BARE-EYE.

Diagnosis.-Distinguished morphometrically from Oneillornis, Gymnopithys, and Rhegmatorhina by large size; bill short compared to body length and deep compared to bill length. Loudsong a short series of simple notes descending in pitch, structurally unique in the complex except for Oneillornis salvini.

\section{Oneillornis new genus}

Type species.-Pithys lunulata Sclater and Salvin, 1873.

Included species.-Oneillornis lunulatus (Sclater and Salvin1873) comb. nov. LunUlated ANTBIRD.

Oneillornis salvini (Berlepsch, 1901) comb. nov. WhITE-THROATED ANTBIRD.

Diagnosis.-Distinguished from Gymnopithys by plumage being sexually dimorphic and from Gymnopithys and Rhegmatorhina by lack of periorbital skin patches and by males being predominantly gray rather than brown. Females differ from females of both genera by having strongly marked tails.

Etymology.-We are pleased to name this genus for our friend and colleague John Patton O'Neill, whose pioneering field work in South America led to the discovery of dozens of new avian species and helped propel the Louisiana State University Museum of Natural Science into becoming one of the great ornithology collections in the world, whose paintings grace our lives and provide keys for field study, and, especially, whose intense love of ornithological exploration and appreciation for the value of museum specimens has been passed on to a multitude of students, one by one, for five decades. The name Oneillornis is masculine in gender.

\section{Gymnopithys Bonaparte, 1857}

Type species.-Turdus rufigula Boddaert, 1783.
Included species.-Gymnopithys rufigula (Boddaert 1783) RUFOUS-THROATED ANTBIRD.

Gymnopithys leucaspis (Sclater 1854) BICOLORED ANTBIRD.

Diagnosis.-Distinguished from Rhegmatorhina and Oneillornis by sexes being alike in plumage (except presence and color of interscapular patch in some taxa). Distinguished from Oneillornis by males primarily brown rather than gray, by females lacking conspicuous tail markings, and by both sexes having periorbital skin patches. Loudsong a series of short notes flat in pitch, then descending sharply.

\section{Rhegmatorhina Ridgway, 1888}

Type species.—Rhegmatorhina gymnops Ridgway, 1888.

Included species.-Rhegmatorhina gymnops Ridgway, 1888. BARE-EYED ANTBIRD.

Rhegmatorhina cristata (Pelzeln, 1869). CHESTNUT-CRESTED ANTBIRD.

Rhegmatorhina melanosticta (Sclater and Salvin 1880). HAIRY-CRESTED ANTBIRD.

Rhegmatorhina berlepschi (Snethlage 1907). HARLEQUIN ANTBIRD.

Rhegmatorhina hoffmannsi (Hellmayr 1907). WHITE-BREASTED ANTBIRD.

Diagnosis.-Distinguished by shaggy crests. From Gymnopithys by sexually dimorphic plumages; females (except $R$. gymnops) with black spotted upperparts. From Oneillornis by male plumage primarily brown rather than gray, by females lacking conspicuous tail markings, and by both sexes having large periorbital skin patches. Loudsong a long note followed by shorter notes starting at a higher pitch and going down scale.

\section{ACKNOWLEDGMENTS}

We are grateful to the curators and collection managers of the American Museum of Natural History (AMNH); Cornell University Museum of Vertebrates (CUMV), Field Museum of Natural History (FMNH), Instituto Nacional de Pesquisas da Amazônia (INPA), Laborátorio de Genética e Evolução de Aves Universidade de São Paulo (LGEMA), Colecão de Ornitologia do Museu de Ciencias e Tecnologia da Pontifícia Universidade Católica do Rio Grande do Sul (MCP), Museu Paraense Emílio Goeldi (MPEG), Museo de Historia Natural de la Universidad de San Marcos (MUSM), Museu de Zoologia Universidade de São Paulo (MZUSP), Smithsonian Tropical Research Institute Bird Collection (STRI), United States National Museum of Natural History (USNM), and University of Washington Burke Museum (UWBM) for providing information and granting access to tissue samples or study specimens under their care. We appreciate the assistance of the Macaulay 
Library, Cornell Laboratory of Ornithology, and B. M. Whitney who provided vocal recordings. N. Aristizábal assisted in obtaining sequences, C. Ribas and A. Aleixo kindly provided unpublished sequences for two individuals, P. R. Isler prepared the illustrations of loudsongs, and N. David reviewed proposed nomenclature. The manuscript benefited substantially from comments by L. F. Silveira, V. de Q. Piacentini, D. F. Lane, and J. V. Remsen, Jr., and review of the submission by R. C. Banks and an anonymous reviewer. This research was supported by grants from the Frank Chapman Memorial Fund - AMNH, the American Ornithologists' Union, the LSUMNS Big Day Fund, LSU Biograds, and NSF grants DBI-0400797, DEB-0841729, and DEB-1011435 to GAB and RTB.

\section{LITERATURE CITED}

Aleixo, A., T. C. T. Burlamaqui, M. P. C Schneider, AND E. C Gonçalves. 2009. Molecular systematics and plumage evolution in the monotypic obligate army-ant-following genus Skutchia (Thamnophilidae). Condor 111:382-387.

Baldwin, S. P., H. C. Oberholser, And L. G Worley. 1931. Measurements of birds. Scientific Publication No. 17. Cleveland Museum of Natural History, Ohio, USA.

BArker, F. K., G. F. BArrowclough, AND J. G. Groth. 2002. A phylogenetic hypothesis for passerine birds: taxonomic and biogeographic implications of an analysis of nuclear DNA sequence data. Proceedings of the Royal Society B-Biological Sciences 269:295-308.

BAtES, H. W. 1863. The naturalist on the River Amazons. John Murray, London, UK.

Bravo, G. A., J. V. Remsen, JR., B. M. Whitney, And R. T. BRUMFIELD. 2012. DNA sequence data reveal a subfamily-level divergence within Thamnophilidae (Aves: Passeriformes). Molecular Phylogenetics and Evolution 65:287-293.

Brumfield, R. T., J. G. Tello, Z. A. Cheviron, M. D. Carling, N. Crochet, and K. V. Rosenberg. 2007. Phylogenetic conservatism and antiquity of a tropical specialization: army-ant-following in the typical antbirds (Thamnophilidae). Molecular Phylogenetics and Evolution 45:1-13.

Buehler, D. M., A. I. Castillo, and J. D. Brawn. 2004. First nest description for the Ocellated Antbird (Phaenostictus mcleannani). Wilson Bulletin 116: 277-279.

Chesser, R. T. 1995. Comparative diets of obligate antfollowing birds at a site in northern Bolivia. Biotropica 27:382-390.

Class, A. M. And J. Chaves-Campos. 2009. Additional notes on the nest location and parental care of Ocellated Antbirds (Phaenostictus mcleannani). Ornitología Neotropical 20:445-459.

Cory, C. B. And C. E. Hellmayr. 1924. Catalogue of birds of the Americas and the adjacent islands. Pteroptochidae-Conopophagidae-Formicariidae. Field Museum of Natural History Zoological Series, No. 13, Part III.

Derryberry, E. P., S. Claramunt, G. Derryberry, R. T. Chesser, J. Cracraft, A. Aleixo, J. Pérez-Emán,
J. V. REMSEN, JR., AND R. T. BRUMFIELD. 2011. Lineage diversification and morphological evolution in a large-scale continental radiation: The Neotropical ovenbirds and woodcreepers (Aves: Furnariidae). Evolution 65:2973-2986.

Drummond, A. J., B. Ashton, S. Buxton, M. Cheung, A. Cooper, C. Duran, M. Field, J. Heled, M. Kearse, S. Markowitz, R. Moir, S. Stone-Havas, S. Sturrock, T. Thierer, AND A. Wilson. 2011. Geneious V5.4. www.geneious.com/

Gómez, J. P., G. A. Bravo, R. T. Brumfield, J. G. Tello AND C. D. CADENA. 2010. A phylogenetic approach to disentangling the role of competition and habitat filtering in community assembly of Neotropical forest birds. Journal of Animal Ecology 79:1181-1192.

Graves, G. R. 1992. Diagnosis of a hybrid antbird (Phlegopsis nigromaculata $\times$ Phlegopsis erythroptera) and the rarity of hybridization among suboscines. Proceedings of the Biological Society of Washington 105:834-840.

Groth, J. G. AND G. F. Barrowclough. 1999. Basal divergence in birds and phylogenetic utility of the nuclear RAG-1 gene. Molecular Phylogenetics and Evolution 12:115-123.

HellmayR, C. E. 1907. [Descriptions of new birds from Brazil.] Bulletin of the British Ornithologist's Club 19:51-55.

Huelsenbeck, J. P. AND F. RonQuist. 2001. MRBAYES: Bayesian inference of phylogeny. Bioinformatics 17:754-755.

Isler, M. L., G. A. Bravo, And R. T. BRumfield. 2013. Taxonomic revision of Myrmeciza (Aves: Passeriformes: Thamnophilidae) into 12 genera based on phylogenetic, morphological, behavioral, and ecological data. Zootaxa 3717:469-497.

IsLeR, M. L. AND B. M. Whitney. 2011. Species limits in antbirds (Thamnophilidae): the Scale-backed Antbird (Willisornis poecilinotus) complex. Wilson Journal of Ornithology 123:1-14.

Katoh, K., K. Misawa, K. I. Kuma, And T. Miyata. 2002. MAFFT: a novel method for rapid multiple sequence alignment based on fast Fourier transform. Nucleic Acids Research 30:3059-3066.

Miller, M. A., W. Pfeiffer, And T. Schwartz. 2010. Creating the CIPRES Science Gateway for Inference of Large Phylogenetic Trees. Pages 1-8 in Proceedings of the Gateway computer environments workshop, New Orleans, Louisiana, USA.

Moyle, R. G., R. T. Chesser, R. T. Brumfield, J. G. Tello, D. J. Marchese, and J. Cracraft. 2009. Phylogeny and phylogenetic classification of the antbirds, ovenbirds, woodcreepers, and allies (Aves: Passeriformes; infraorder Furnariides). Cladistics 25:1-20.

NAKa, L. N., C. L. Bechtoldt, L. M. P. HenRiQues, AND R. T. BRUMFIELD. 2012. The role of physical barriers in the location of avian suture zones in the Guiana Shield, northern Amazonia. American Naturalist 179:E115-E132.

NylandeR, J. A. A. 2004. MrModeltest. Version 2. Evolutionary Biology Center, Uppsala, Sweden. 
Peterson, A. T., R. G. Moyle, A. S. Nyári, M. B. Robbins, R. T. BRUMFIELD, AND J. V. REMSEN JR. 2007. The need for proper vouchering in phylogenetic studies of birds. Molecular Phylogenetics and Evolution 45:1042-1044.

Remsen, J. V., JR., C. D. CAdena, A. Jaramillo, M. Nores, J. F. PACheco, J. Pérez-Emán, M. B. Robbins, F. G. Stiles, D. F. StotZ, And K. J. Zimmer. 2013. A classification of the bird species of South America. Version [30 Aug 2013]. American Ornithologists' Union. www.museum.lsu.edu/ Remsen/SACCBaseline.html.

StAMATAKIS, A. 2006. RaxML-VI-HPC: maximum likelihood-based phylogenetic analysis with thousands of taxa and mixed models. Bioinformatics 22:2688-2690.

SwOFFord, D. L. 2003. PAUP*. Phylogenetic analysis using parsimony (*and other methods). V4. Sinauer Associates, Sunderland, Massachusetts, USA.
Wilgenbusch, J. C., D. L. Warren, And D. L. Swofford. 2004. AWTY: A system for graphical exploration of MCMC convergence in Bayesian phylogenetic inference. Available from ceb.csit.fsu.edu/awty (accessed 1 Nov 2011).

WiLlis, E. O. 1968. Taxonomy and behavior of Pale-faced Antbirds. Auk 85:253-264.

Willis, E. O. AND Y. ONIKI. 1978. Birds and army ants. Annual Review of Ecology and Systematics 9:243-263.

WILLSON, S. K. 2004. Obligate army ant-following birds: a study of ecology, spatial movement patterns, and behavior in Amazonian Peru. Ornithological Monographs 55:1-67.

Zimmer, K. J. AND M. L. ISLER. 2003. Family Thamnophilidae (typical antbirds). Pages 448-681 in Handbook of the Birds of the World. Volume 8. Broadbills to tapaculos (J. del Hoyo, A. Elliot and D. A. Christie, Editors). Lynx Edicions, Barcelona, Spain.

APPENDIX 1. Ingroup taxa used in this study and their respective tissue collection catalog number. Sample numbers followed by an asterisk identify samples used in all analyses; remaining specimens were sequenced only for ND2. For museum acronyms see acknowledgements.

\begin{tabular}{|c|c|c|c|c|}
\hline Sample & Species & Locality & Voucher & Tissue \\
\hline $1 *$ & Pithys a. albifrons & Brazil: Amapá & FMNH 391430 & FMNH 391430 \\
\hline 2 & Pithys albifrons peruvianus & Brazil: Amazonas & INPA MA439 & INPA A-1138 \\
\hline $3 *$ & Pithys castaneus 1 & Peru: Loreto & MUSM KE157 & LSUMZ B-42817 \\
\hline 4 & Pithys castaneus 2 & Peru: Loreto & LSUMZ 177297 & LSUMZ B-42901 \\
\hline $5 *$ & Gymnopithys leucaspis bicolor & Panama: Darién & LSUMZ 108844 & LSUMZ B-2096 \\
\hline 6 & Gymnopithys leucaspis olivascens & Panama: Bocas del Toro & CUMV 51302 & STRI JTW268 \\
\hline $7 *$ & Gymnopithys leucaspis lateralis 1 & Peru: Loreto & LSUMZ 115499 & LSUMZ B-4136 \\
\hline 8 & Gymnopithys leucaspis lateralis 2 & Peru: Loreto & LSUMZ 115502 & LSUMZ B-4290 \\
\hline 9 & Gymnopithys leucaspis lateralis 3 & Brazil: Amazonas & INPA ITM108 & INPA A-1997 \\
\hline 10 & Gymnopithys leucaspis lateralis 4 & Brazil: Amazonas & INPA ITM98 & INPA A-1942 \\
\hline 11 & Gymnopithys leucaspis lateralis 5 & Brazil: Amazonas & INPA MFT98 & INPA A-1137 \\
\hline $12 *$ & Gymnopithys rufigula pallidus & Venezuela: Amazonas & FMNH 319276 & LSUMZ B-7512 \\
\hline 13 & Gymnopithys $r$. rufigula 1 & $\begin{array}{l}\text { Suriname: Sipaliwini } \\
\text { Distrikt }\end{array}$ & LSUMZ 178459 & LSUMZ B-55217 \\
\hline 14 & Gymnopithys $r$. rufigula 2 & Brazil: Amazonas & INPA GAB209 & INPA A-1599 \\
\hline 15 & Gymnopithys $r$. rufigula 3 & Brazil: Roraima & INPA MASJR30 & INPA A-1073 \\
\hline 16 & Gymnopithys $r$. rufigula 4 & Brazil: Amazonas & INPA LNN300 & INPA A-1232 \\
\hline 17 & Gymnopithys $r$. rufigula 5 & Brazil: Amazonas & INPA MA464 & INPA A-1200 \\
\hline $18^{*}$ & Gymnopithys salvini 1 & Bolivia: La Paz & FMNH 391147 & FMNH 391147 \\
\hline 19 & Gymnopithys salvini 2 & Brazil: Amazonas & MPEG 55232 & LSUMZ B-35718 \\
\hline $20 *$ & Gymnopithys lunulata 1 & Peru: Loreto & LSUMZ 161783 & LSUMZ B-27384 \\
\hline 21 & Gymnopithys lunulata 2 & Peru: Loreto & MUSM JAA96 & LSUMZ B-42895 \\
\hline $22 *$ & Rhegmatorhina gymnops 1 & Brazil: Pará & MPEG 54707 & LSUMZ B-35336 \\
\hline $23 *$ & Rhegmatorhina gymnops 2 & Brazil: Pará & MPEG 54687 & LSUMZ B-35298 \\
\hline $24 *$ & Rhegmatorhina berlepschi 1 & Brazil: Pará & MPEG 20350 & MPEG 20350 \\
\hline $25^{*}$ & Rhegmatorhina berlepschi 2 & Brazil: Pará & MPEG 20404 & MPEG 20404 \\
\hline $26^{*}$ & Rhegmatorhina hoffmannsi 1 & Brazil: Rondônia & FMNH 389933 & FMNH 389933 \\
\hline 27 & Rhegmatorhina hoffmannsi 2 & Brazil: Rondônia & MPEG 55001 & LSUMZ B-36786 \\
\hline $28^{*}$ & Rhegmatorhina cristata 1 & Brazil: Amazonas & INPA LNN261 & INPA A-1136 \\
\hline 29 & Rhegmatorhina cristata 2 & Brazil: Amazonas & INPA MFT99 & INPA A-1139 \\
\hline $30 *$ & Rhegmatorhina m. melanosticta & Peru: Loreto & LSUMZ 115512 & LSUMZ B-4248 \\
\hline 31 & Rhegmatorhina melanosticta purusiana & Bolivia: Pando & LSUMZ 132987 & LSUMZ B-9734 \\
\hline 32 & Willisornis p. poecilinotus 1 & Brazil: Roraima & INPA LNN234 & INPA A-1060 \\
\hline 33 & Willisornis p. poecilinotus 2 & Brazil: Roraima & INPA LNN427 & INPA A-1790 \\
\hline 34 & Willisornis poecilinotus duidae 1 & Brazil: Amazonas & INPA CLB65 & INPA A-655 \\
\hline
\end{tabular}




\begin{tabular}{|c|c|c|c|c|}
\hline Sample & Species & Locality & Voucher & Tissue \\
\hline 35 & Willisornis poecilinotus duidae 2 & Brazil: Amazonas & INPA MA460 & INPA A-1193 \\
\hline $36^{*}$ & Willisornis poecilinotus griseiventris 1 & Bolivia: La Paz & FMNH 391148 & FMNH 391148 \\
\hline $37 *$ & Willisornis poecilinotus griseiventris 2 & Brazil: Rondônia & MCP 2362 & MCP 2362 \\
\hline $38 *$ & Willisornis v. vidua 1 & Brazil: Pará & MPEG 53293 & LSUMZ B-16954 \\
\hline $39 *$ & Willisornis v. vidua 2 & Brazil: Pará & MPEG 53292 & LSUMZ B-16956 \\
\hline 40 & Phlegopsis $n$. nigromaculata 1 & Peru: Loreto & LSUMZ 110203 & LSUMZ B-2813 \\
\hline 41 & Phlegopsis $n$. nigromaculata 2 & Brazil: Acre & MPEG 59868 & MPEG 59868 \\
\hline $42 *$ & Phlegopsis nigromaculata bowmani 1 & Brazil: Rondônia & FMNH 389842 & FMNH 389842 \\
\hline 43 & Phlegopsis nigromaculata bowmani 2 & Brazil: Pará & MPEG 58133 & MPEG 58133 \\
\hline 44 & Phlegopsis nigromaculata bowmani 3 & Brazil: Pará & MPEG 56103 & MPEG 56103 \\
\hline 45 & Phlegopsis nigromaculata confinis & Brazil: Pará & MPEG 55694 & MPEG 55694 \\
\hline 46 & Phlegopsis nigromaculata paraensis & Brazil: Pará & MPEG 58980 & MPEG 58980 \\
\hline 47 & Phlegopsis e. erythroptera 1 & Brazil: Amazonas & MPEG 59609 & MPEG 59609 \\
\hline 48 & Phlegopsis e. erythroptera 2 & Peru: Loreto & LSUMZ 110219 & LSUMZ B-2707 \\
\hline $49 *$ & Phlegopsis erythroptera ustulata 1 & Bolivia: Pando & LSUMZ 133046 & LSUMZ B-9617 \\
\hline 50 & Phlegopsis erythroptera ustulata 2 & Brazil: Amazonas & MPEG 57142 & MPEG 57142 \\
\hline $51 *$ & Phlegopsis borbae 1 & Brazil: Mato Grosso & MZUSP 96631 & LGEMA P44 \\
\hline 52 & Phlegopsis borbae 2 & Brazil: Amazonas & MPEG 58755 & MPEG 58755 \\
\hline 53 & Phlegopsis borbae 3 & Brazil: Amazonas & MPEG 57694 & MPEG 57694 \\
\hline 54 & Phlegopsis borbae 4 & Brazil: Amazonas & MPEG 57691 & MPEG 57691 \\
\hline 55 & Phlegopsis borbae 5 & Brazil: Amazonas & MPEG 57693 & MPEG 57693 \\
\hline $56 *$ & Phaenostictus m. mcleannani 1 & Panama: Darién & LSUMZ 108372 & LSUMZ B-2135 \\
\hline 57 & Phaenostictus m. mcleannani 2 & Panama: Darién & LSUMZ 104693 & LSUMZ B-1390 \\
\hline
\end{tabular}

\section{APPENDIX 2.}

The following list identifies specimens measured in this study. For museum acronyms see acknowledgements. Pithys albifrons (LSUMZ 116931, O’; MPEG 59533, ᄋ; MPEG 64725, or; MPEG 65800, ○), Pithys castaneus (LSUMZ 172973, ᄋ; LSUMZ 172975, O’; LSUMZ 172974, o; LSUMZ 172977, O’), Gymnopithys leucaspis (LSUMZ 180750, O;; LSUMZ 112584, O’; LSUMZ 164166, O’; LSUMZ 108359, ९; LSUMZ 83240, ९; MPEG 59538, ᄋ; MPEG 42708, O’; LSUMZ 110147, ᄋ; LSUMZ 116946, O*), Gymnopithys rufigula (LSUMZ 68553, O’; MPEG 43772, O’; MPEG 66153, ᄋ; LSUMZ 178461, ᄋ; LSUMZ 178459, क; LSUMZ 175423, o), Gymnopithys salvini (LSUMZ 132956, O’; MPEG 54997, ơ; MPEG 49484, ᄋ; LSUMZ 78519, ९), Gymnopithys lunulatus (LSUMZ 161784, o; LSUMZ 110124, ơ; LSUMZ 161783, O'; LSUMZ 172980, o), Rhegmatorhina gymnops (USNM 120960, ᄋ; MPEG 65697, O’; MPEG 59153, O’; MPEG 67657, ᄋ; MPEG 59152, ᄋ), Rhegmatorhina berlepschi (AMNH 286932, o'; MZUSP 76331, ᄋ; MZUSP 76333, ᄋ; MZUSP
76332, O'), Rhegmatorhina hoffmansi (AMNH 491345, O’; MPEG 39791, O’; MPEG 57682, O"; MPEG 39808, o; MPEG 57686, ᄋ), Rhegmatorhina cristata (LSUMZ 104957, ᄋ; MPEG 55865, o; MPEG 42724, o'; MPEG 42725, ᄋ), Rhegmatorhina melanosticta (LSUMZ 115512, O'; MPEG 52172, ᄋ; MPEG 60021, O'; LSUMZ 132982, ᄋ), Willisornis poecilinotus (MPEG 65805, ᄋ; LSUMZ 110185, O’; MPEG 59581, O;; MPEG 59579, ᄋ; MPEG 58216, O’; MPEG 57264, ᄋ; MPEG 56232, O’; MPEG 55666, ᄋ), Willisornis vidua (MPEG 61128, O’; MPEG 61125, ᄋ; LSUMZ 67352, O’; LSUMZ 67349, O), Phlegopsis nigromaculata (LSUMZ 137280, O'; MPEG 57368, ᄋ; MPEG 51986, O’; LSUMZ 110205, O), Phlegopsis erythroptera (LSUMZ 110211, O’; MPEG 59607, o; MPEG 60731, O;; MPEG 57146, O), Phlegopsis borbae (AMNH 491993, ơ; MZUSP 84827, or; MZUSP 84826, ○; MZUSP 84825, O’; MZUSP 80544, ९), Phaenostictus mcleannani (LSUMZ 163606, o; LSUMZ 104693, ᄋ; LSUMZ 177738, ơ; LSUMZ 108372, ᄋ'). 